\title{
Assessment of Informal Cross-Border Fish Trade in the Southern Africa Region: A Case of Malawi and Zambia
}

\author{
Happy Mussa ${ }^{1}$, Emmanuel Kaunda ${ }^{1}$, Sloans Chimatiro ${ }^{2}$, Keagan Kakwasha ${ }^{2}$, Lisungu Banda ${ }^{3}$, Bonface \\ Nankwenya $^{3}$ and Jabulani Nyengere ${ }^{1}$ \\ 1. Department of Aquaculture and Fisheries Science, Lilongwe University of Agriculture and Natural Resources, Bunda Campus,
} Lilongwe 219, Malawi

2. WorldFish Center, Zambia Office, Katima Mulilo Road, Lusaka 51289, Zambia

3. Department of Agriculture and Applied Economics, Lilongwe University of Agriculture and Natural Resources, Bunda Campus, Lilongwe 219, Malawi

\begin{abstract}
Intra-regional fish trade has potential in addressing the region's food and nutrition insecurity, as well as poverty reduction, by enabling movement of fish from countries of surplus to those with deficit. However, informal fish trade, just like all informal economic activities, has been overlooked and neglected in many national and regional policies, leading to obscurity of such an important part of the fisheries sector. This study examined the situation in the cross-border informal fish trade in order to deepen our understanding about the traders, the factors influencing the traders to use informal trade channels, the structure of the products traded and the challenges traders face, as well as propose policy direction to enhance the cross-border fish trade in the Southern Africa region. The study revealed that female traders dominated informal fish trade. In both Malawi and Zambia, an estimated 45,285.52 metric tonnes of fish valued at 82.14 million dollars and 102,263.9 metric tonnes of fish valued at 3.3 million dollars were informally traded. The key species involved in informal cross-border trade in Malawi and Zambia were the small pelagics, usipa (Engraulicypris sardella) from Lake Malawi and dagaa (Rastrineobola argentea) from Lake Tanganyika, respectively. It emerged from focus group discussions with informal fish traders and key informants' interviews with border post fish inspection and revenue collection officials that traders are put off by the cross-border regulations. Therefore, it is important for countries in the Southern African Development Community (SADC) region to regularize and formalize cross-border trade, particularly in small pelagic fish species, since this species plays a great role in the livelihoods, food and nutrition security of many people in the region, especially the rural and urban poor. It is also important for governments to support processors and traders to improve the quality of fish being traded, and decentralize issuing of the import/export certificates and other cross-border support documents. Lastly, there is a need to establish informal fish trade monitoring systems to adequately quantify the volumes traded.
\end{abstract}

Key words: Informal fish trade, small pelagic species, Malawi, Zambia.

\section{Introduction}

Africa's participation in the global fish trade is fairly limited and represents approximately $4.9 \%$ of total value of commodities traded. By value, Africa was a net exporter since 1985 (except 2011), reflecting the lower unit value of imports mainly for small pelagic species [1]. In addition to limited global participation, Africa's capacity for intra-regional trade

Corresponding author: Happy Mussa, M.Sc., research fields: aquaculture economics, trade and policy. is also low. As a result, official intra-African trade was just $11 \%$ of the continent's total trade between 2007 and 2011 [2]. While Africa is losing shares in the global markets and trading relatively less with itself, intra-regional trade in fish is encouraging, reported to be $24 \%$ between 2010 and 2012 [3]. Consequently, fish was reported to be the second most traded agricultural commodity intra-regionally, after sugar [4]; and recently, World Trade Report 2014 [5] cited cotton, coffee and fish to be among agricultural commodities with export potential. Despite the 
potential of intra-regional fish trade in addressing the region's food and nutrition insecurity, as well as poverty reduction through wealth creation, this type of trade is often overlooked and neglected in national and regional policy. While the last 50 years have seen an increase in the role of market surplus from artisanal fisheries within capitalist economies, the inherent complexity of artisanal fisheries makes it difficult to understand their specific relevance to an area's livelihoods and food security [6]. As a result, intra-regional fish trade has largely remained informal, with low volumes traded by artisanal and small-medium enterprises, most of which are headed by women.

Concerned about the low level of intra-regional trade, the African Union (AU) Heads of State and Government, during their 23rd Ordinary Summit in Malabo, Equatorial Guinea in June 2014 (also known as Malabo Declaration) [7], committed themselves to triple, by the year 2025, intra-African trade in agricultural commodities (including fish) and services. With regard to fisheries, the heads of state further expressed their concern "over the limited value addition in fisheries and aquaculture coupled with the high level of post-harvest losses, especially in small scales fisheries and the absence of specific financial mechanism to support SMEs". Subsequently, part of the Malabo Declaration included endorsement of the AU Policy Framework and Reform Strategy for Fisheries and Aquaculture in Africa, and committed themselves to "accelerate trade by developing fish value chains, promoting responsible and equitable fish trade and marketing in order to significantly harness the benefits of Africa's fisheries and aquaculture endowments".

Fish and fishery products are ranked among the most traded food commodities globally, with developing countries accounting for the bulk of the world's fish exports [8]. Fish and fishery products exported from developing countries comprise $20 \%$ of all agricultural and food processing exports. According to the FAO "State of the World's Fisheries and Aquaculture", it is estimated that world trade in fish and fishery products has grown significantly also in value terms, with exports rising from US\$8 billion in 1976 to US $\$ 148$ billion in 2014 , at an annual growth rate of $8 \%$ in nominal terms and $4.6 \%$ in real terms [1]. In 2014, fishery exports from developing countries were valued at US\$80 billion, and their fishery net-export revenues (exports minus imports) reached US\$42 billion, higher than other major agricultural commodities (such as meat, tobacco, rice and sugar) combined [1]. On the whole, it has been observed that the global demand for fish is increasing [9].

Information on the informal cross-border fish trade is scanty $[10,11]$, though trade in fish and fish products is becoming increasingly important for most country's food security and economic development. However, informal fish trade, just like all informal economic activities, has been overlooked and neglected in many national and regional policies, leading to obscurity of such an important part of the fisheries sector. Due to lack of information on the value of informal fish trade, it is hard to quantify the total real value of trade. As a result, the value of fish trade is overlooked and neglected in national policies, leading to less attention to the sector, as figures are way less than actual situation on the ground. The study, therefore, tried to examine the situation in the cross-border informal fish trade in Malawi and Zambia with neighbouring countries to understand the traders' demography and also to uncover unfilled demand in the cross-border markets, quantify the amount of fish going informally and outline the factors influencing traders to use informal trade channels for policy support.

\section{Methodology}

The trade survey targeted 1,068 respondents, comprising both men and women across seven formal border posts for Malawi (Malawi-Mozambique border (Marka, Muloza, Mwanza, Chiponde), 
Malawi-Mozambique border transit to South Africa

(Dedza), Malawi-Zambia (Mchinji) and Malawi-Tanzania (Songwe)) and four for Zambia (Zambia-Democratic Republic of the Congo (DRC) border (Kasumbalesa), Zambia-Namibia border (Katimamulilo), Zambia-Tanzania border (Nakonde) and Zambia/Mozambique/Zimbabwe border (Luangwa)). These border sites were selected mainly because of their relative importance in fish trade activities and that they are the official border posts for Malawi and Zambia with their neighbouring countries. Both quantitative and qualitative data were collected through household interviews with the informal traders, and key informant interviews with the border post fish inspection and revenue collection officers. Snowball technique was used in sampling out the informal fish traders within the border posts as proposed by Cornelius [12]. The advantage of this sampling method is that it is appropriate to use when the members of a population are difficult to locate where it allows reaching populations that are inaccessible or hard to find [13]. In this case, the few members of the informal fish traders were located and interviewed, and then those were relied to provide information needed to locate informal trade routes (channels) used and other fish traders that use informal channels whom they know. The local people were engaged in data collection since they have the contacts with informants, which gave an opportunity to establish the confidence of informants, and also the locals were perceived to possess rich information on the political context of the area as suggested by Ellis and MacGaffey [14].

Data analysis was done using SPSS (version 22.0) and Microsoft Excel. Descriptive statistics, such as percentages, frequencies and means were used for summarizing and presenting data from informal cross-border fish trader's surveys. Probit regression model was used to assess socio-economic and institution factors influencing the motive for fish traders to participate in the informal cross border fish trade. The model was specified as follows by Eq. (1):

$$
y=\beta_{0}+\beta_{1} X_{i}+\varepsilon_{i}
$$

where, $y$ is binary, 1 (participate) and 0 (otherwise); $X$ is a vector of explanatory variables (occupation, age, gender, source of fish, form of fish, transport mode across border, price of fish in cross-border markets, time period, operational cost, knowledge of policies guiding informal trade, political dynamics between two countries); $\beta$ is a vector of coefficients to be estimated; and $\varepsilon$ is a random error.

Annual trade volumes and values were estimated by using Eqs. (2-4) suggested by Ackello-Ogutu [15]:

$$
\begin{gathered}
A T V=M N\left[\sum_{i=1}^{n} Q_{d} i\right] \\
A D T V=\left[\sum_{i=1}^{n} \mathrm{Q}_{\mathrm{d}} i\right] / J \\
A V=M N\left[\sum_{i=1}^{n} \mathrm{Q}_{\mathrm{d}} i\right] P
\end{gathered}
$$

where, $N$ is the days in a month a trader exported or imported fish from or to the market; $M$ is the number of months in a year during which a trader exported or imported fish; $Q_{d}$ is the quantity of fish exported or imported per day; $J$ is the total number of day's data were collected; $P$ is the average price of fish per unit; $A D T V$ is average daily trade volume; $A T V$ is annual trade volume; $A V$ is annual trade value; and $i$ is the trader index.

\section{Results and Discussion}

\subsection{Demographics of Informal Cross-Border Fish} Traders

Demographics of the informal traders show that both the youth and elders take part in informal fish trade with the minimum reported age of 15 years old and maximum of 72 years old, which makes a clear indication that fisheries and aquaculture sector play an important role in providing a source of livelihood to all age groups in Malawi. In both Malawi and Zambia, informal fish trade was dominated by female traders, 
accounting for $65.7 \%$ and $52.1 \%$, respectively. This is an indication that women play a major role in informal fish trade in the two countries, conforming the figures reported by Economic Commission for Africa [16], where in Benin, women account for $80 \%$ of those involved in informal trade and also the figures were reported to reach 95\% for informal marketing of unprocessed goods and also the United Nations Development Fund for Women (UNDFW) report, which reported that, in the Southern African Development Community (SADC) region, women constitute about $70 \%$ of the informal cross-border traders and nearly $60 \%$ of informal traders in the western and central parts of Africa [17, 18]. Informal traders from three distinct nations were interviewed in Malawi, where $93.7 \%, 6 \%$ and $0.3 \%$ were Malawians, Mozambicans and Tanzanians, respectively. For Zambia, traders involved in informal fish trade were Zambians (79\%), Namibians (11.5\%), Congolese (7\%), Zimbabweans (1.7\%) and South Africans (0.7\%) (Table 1).

\subsection{Fish and Fish Products Traded Informally in} Malawi and Zambia

Malawi informally trade fish with its immediate neighbouring Mozambique, Zambia and Tanzania. Between 2015 and 2016, annual informal fish exports from Malawi to these countries were estimated at $24,115.68$ metric tonnes valued at 41.6 million dollars, which outstripped informal imports by $9,633.84$ metric tonnes. By destination, Mozambique was the major importing country, which informally imported $16,584.48$ metric tonnes with the same period valued at 28.8 million dollars. Zambia comes second, importing an estimated 11,399.20 metric tonnes valued at 21.6 million dollars and Tanzania imported 2,820 metric tonnes informally valued at 8.2 million dollars.

Amongst the fish species exported informally, usipa (Engraulicypris sardella) a small pelagic species from Lake Malawi was the most traded fish species, where an estimated 20,923.84 metric tonnes valued at 37.9 million dollars were exported to all the three neighbouring countries (Mozambique, Zambia and Tanzania). This phenomenon correlates with the production levels for usipa, which accounts for $70 \%$ of the catches from Lake Malawi [19]. The other fish species informally between Malawi and her neighbouring countries were matemba (Barbus paludinosus), utaka (Copadichromis species), chambo

Table 1 Demographics of informal fish traders.

\begin{tabular}{|c|c|c|c|c|c|}
\hline \multirow{2}{*}{ Variable } & & \multicolumn{2}{|c|}{ Zambia $(n=286)$} & \multicolumn{2}{|c|}{ Malawi $(n=782)$} \\
\hline & & Frequency & Percent & Frequency & Percent \\
\hline \multirow{4}{*}{ Age (years) } & $15-29$ & 31 & 10.8 & 201 & 25.7 \\
\hline & $30-39$ & 197 & 68.9 & 422 & 54.0 \\
\hline & $40-49$ & 41 & 14.3 & 128 & 16.4 \\
\hline & 50 above & 17 & 5.9 & 31 & 4.0 \\
\hline \multirow{2}{*}{ Gender } & Male & 137 & 47.9 & 268 & 34.3 \\
\hline & Female & 149 & 52.1 & 514 & 65.7 \\
\hline \multirow{9}{*}{$\begin{array}{l}\text { Nationality of } \\
\text { traders }\end{array}$} & Malawi & - & - & 733 & 93.7 \\
\hline & Mozambique & - & - & 47 & 6.0 \\
\hline & Tanzania & - & - & 2 & 0.3 \\
\hline & Zambia & 226 & 79.0 & - & - \\
\hline & DRC & 20 & 7.0 & - & - \\
\hline & Namibia & 33 & 11.5 & - & - \\
\hline & South Africa & 2 & 0.7 & - & - \\
\hline & Zimbabwe & 1 & 0.3 & - & - \\
\hline & Non response & 4 & 1.4 & - & - \\
\hline
\end{tabular}

\footnotetext{
-: Not applicable.
} 
(Oreochromis spp.), mlamba (Clarias gariepinus), ncheni (Rhamphochromis spp.), mbaba (Buccochromis spp.), njole (Labeo altivelis), makakana (Oreochromis mossambicus), bakayawo (unidentified), chikowa (unidentified), jamison (Diplotaxodon argenteus), carapau (Scomber spp.) and prawns (Penaeus monodon). The findings showed how important the small pelagic fish species were to the ever growing population of the sub-Saharan Africa, suggesting the immediate needs to sustainably manage the small pelagics in water bodies.

For the case of Zambia, from the four border posts where the fish trade survey and border monitoring were undertaken for 2015/2016, an estimated 102,263.9 metric tonnes of fish valued at 3.3 million dollars were informally traded between Zambia and her neighbours. Of the 102,263.9 metric tonnes of fish, 95\% (97,119.06 metric tonnes) with an estimated value of 3.1 million dollars were informally exported to DRC through Kasumbalesa border (Zambia/DRC) (Appendix 2) and the possible explanation to that is the escalation of civil conflict in DRC, which has severely damaged local livelihood systems, including farming, resulting in high demand for food items, hence providing opportunities for trade according to FEWS NET [20]. The official national statistics show that Zambia is a net importer of fish commodities. For example, in 2015, statistics show that Zambia imported 77,199.2 tonnes of fish while exported 334.3 tonnes [21]. However, fish trade study findings indicate that Zambia imports fish, which is then re-exported to neighboring countries and mostly through the informal trade channels. Despite huge quantities of fresh sea fish are landed in Zambia every year, almost $99 \%$ of them end up in DRC by informal trading through Kasumbalesa border post. This situation has arisen due to political instability in DRC in the past few years of which most traders are not willing to take the risk [21].

Among the fish species traded informally in Zambia (Fig. 1) are tilapia (Tilapia spp.), baibai (open smoked or sundried Tilapia spp.), bottle fish (Mormyrus longirostris), buka-buka (Lates stappersii), catfish (Clarias gariepinus), horse mackerel, popa (Haplochromis spp.), tigerfish (Hydrocynus vittatus), kapenta (clupeids species), makombo (Serranochromis spp.), tomso and chinyonge (smoked L. stappersii). Again, dagaa (Rastrineobola argentea), a Lake Tanganyika pelagic species, was the most traded fish species. It was learnt from the fish trade survey that tilapia is imported from China which lands in Zambia as its final destination; however, the fish is then re-exported to other countries, mostly through informal trade routes.

\subsection{Factors Influencing Traders to Use Informal} Trade Routes

Results of a probit model that was run to examine the factors influencing the trader's decision to either participate or not in the informal cross-border fish trade revealed that knowledge of policy regarding informal trade and number of people involved in the fish supply chain was the significant factor influencing fish traders in Zambia to use informal fish trade routes. Both factors had a negative coefficient implying a reduction in participation in informal trade in the occurrence of those factors. In Zambia, traders preferred to use informal trade routes, because most of them claim to have not been aware of the policies guiding the cross-border trade. Therefore, it might be deduced that once fish traders are made aware of the policies regarding cross-border fish trade, they are less likely to use informal border crossings. Also, the traders are less likely to participate in the informal trade when the number of people involved in the fish supply chain increases. The likely interpretation of the inverse relationship between number of people and informal trade could be that increase in number of people involved in cross-border trade leads to increase in number of people employed in the chain, and hence indirectly increase the operation costs, leading to reduced revenue generated. Alternatively, this could 


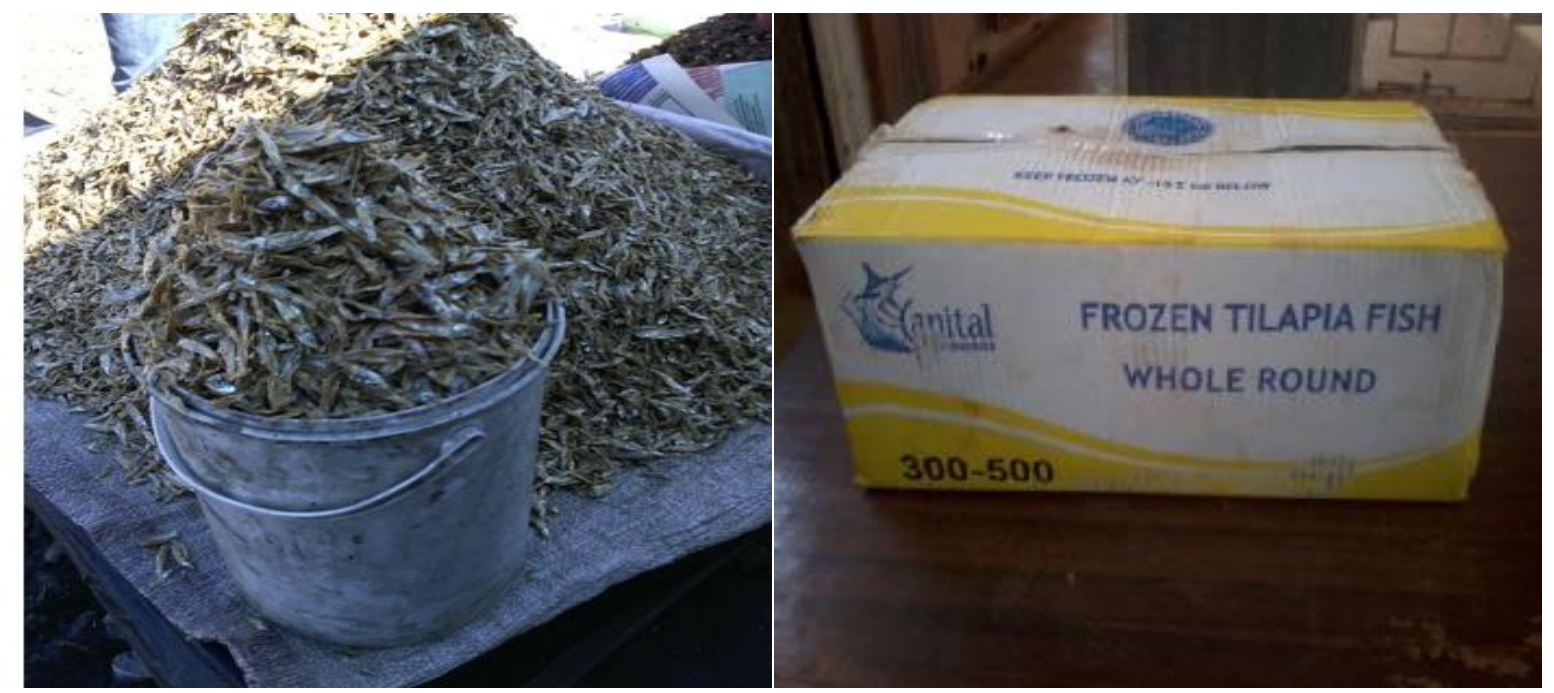

Fig. 1 Some of the fish species traded informally: salted and sundried kapenta (left) and frozen Chinese tilapia (right).

also mean that large traders involved in the trade flood the markets and depress the prices, and again leading to reduced revenues. Abbott et al. [6] also reported that the rise in the number of fish vendors at Katimamulilo market (border between Zambia and Namibia), further reduced the potential profit. An analysis of socio-economic and institutional factors indicates that trading informally between Zambia and DRC has a positive coefficient, which indicates that informal fish trading is more concentrated around Kasumbalesa (Zambia-DRC) border. This may indicate that Kasumbalesa is the most porous border in Zambia.

Environmental and socio-economic forces are said to shape artisanal fishery marketing channels in many ways, including growing urban demand, local decline in fish biomass, which favour large-scale aggregators and imports [6]. Abbott et al. [6] further reported that global demand for primary commodities, such as copper, which is the main export commodity for both Zambia and DRC, has led to economic growth, in turn, has created centres of prosperity, and hence an increased demand for animal protein. Therefore, centres of prosperity in DRC across the Kasumbalesa border could be one of the key factors behind the push for informal flow of fish products from Zambia to DRC. Although mode of transport did not show significant effect in the model (Table 2), improvement of transport network between Zambia and DRC could also have contributed to large volume of informal trade between the two countries through. Abbott et al. [6] reported bundles of fish being carried by lorries to Kasumbalesa, where the fish is traded further north to feed mine laborers within the DRC. It is important to note that DRC is also the main destination of fish from Lake Vitoria. As reported by Medard et al. [22], that DRC is the major recipient of Nile perch by-products from Kirumba market, accounting for $70 \%-80 \%$ of sales.

In Malawi, gender, form of fish, mode of transport across border, operation costs, period of time it takes to gather fish, price of fish in cross-border markets, knowledge of policy regarding informal trade, political dynamics and trading between Malawi and Mozambique were found to be significant factors influencing fish traders to use informal trade routes (Table 2). Form of fish, knowledge of policy regarding informal trade, price of fish in cross-border markets and trading between Mozambique had positive coefficients, implying that these were the factors influencing more participation in informal cross-border trade. Gender, mode of transport, period of time to gather fish before taking to cross-border markets, operation costs and unfavorable political 
Table 2 Factors influencing decision of traders to participate in informal fish trade in Malawi and Zambia.

\begin{tabular}{|c|c|c|c|c|c|c|}
\hline \multirow[b]{2}{*}{ Variable } & \multicolumn{3}{|c|}{ Malawi } & \multicolumn{3}{|c|}{ Zambia } \\
\hline & Coefficients & Standard error & $p>z$ & Coefficients & Standard error & $p>z$ \\
\hline Age & 0.0027384 & 0.00557 & 0.623 & -0.0024763 & 0.00212 & 0.243 \\
\hline Gender & -0.234529 & 0.06112 & $0.000^{* * *}$ & -0.0343937 & 0.03041 & 0.258 \\
\hline Source & -0.2650314 & 0.39318 & 0.5 & 0.1152703 & 0.09715 & 0.235 \\
\hline Form of fish & 0.3586229 & 0.1617 & $0.027^{* * *}$ & 0.0073176 & 0.04753 & 0.878 \\
\hline Mode of transport & -0.3284891 & 0.07266 & $0.000^{* * * *}$ & 0.051594 & 0.0487 & 0.289 \\
\hline $\begin{array}{l}\text { Number of people } \\
\text { involved in the chain }\end{array}$ & -0.0051101 & 0.00336 & 0.128 & -0.0002245 & 0.00006 & $0.00^{* * * *}$ \\
\hline Volumes of fish traded & -0.0004726 & 0.00038 & 0.218 & 0.0237946 & 0.04414 & 0.59 \\
\hline Time period & -0.0221076 & 0.0077 & $0.004^{* * *}$ & 0.0237946 & 0.04414 & 0.59 \\
\hline Cost & -1.8807 & 0 & 0.736 & -0.0659826 & 0.02761 & $0.017^{* *}$ \\
\hline $\begin{array}{l}\text { Knowledge of policies } \\
\text { regarding informal trade }\end{array}$ & 0.1635838 & 0.07471 & $0.029^{* *}$ & -0.0110833 & 0.03573 & 0.756 \\
\hline $\begin{array}{l}\text { Influence of political } \\
\text { dynamics }\end{array}$ & -0.160409 & 0.10764 & 0.136 & -0.0138736 & 0.01087 & 0.202 \\
\hline Price & 0.0000497 & 0.00003 & 0.076 & 0.0217723 & 0.04153 & 0.6 \\
\hline Dummy-Mozambique & 0.8400503 & 0.05563 & $0.000^{* * *}$ & - & - & - \\
\hline Dummy-DRC & - & - & - & -0.0002245 & 0.00006 & $0.00^{* * * *}$ \\
\hline LR $\operatorname{chi}^{2}(13)$ & 257.61 & & & 45.82 & & \\
\hline Prob $>\mathrm{chi}^{2}$ & 0.000 & & & 0.0000 & & \\
\hline Pseudo $R^{2}$ & 0.6299 & & & 0.2730 & & \\
\hline Log likelihood & -75.683476 & & & -61.020401 & & \\
\hline
\end{tabular}

${ }^{* *}$ Significant at $p<0.05,{ }^{* * *}$ significant at $p<0.01,-:$ not applicable.

environment had negative coefficient. This shows that female traders were more likely to participate in informal trade, unlike their male counterparts. Increase in time taken to gather fish and operation costs makes traders less likely to participate in informal trade. The findings agree with studies in work preference, which have shown that men are more likely than women to seek jobs in which competition with coworkers affects pay rates [23].

\subsection{Political Environment Influencing Fish Traders to Use Informal Trade Channels}

The study further revealed some of the administrative or governmental reasons why traders use informal trade channels. It emerged from focus group discussions with informal fish traders and key informants interviews with border post fish inspection and revenue collection officials across the seven formal border posts of Malawi that traders are put off by the cross-border regulations that are restrictive, which agrees with the findings by Economic Commission for Africa [16]. In order to export or import fish, traders are required to possess a sanitary certificate, export and import permit, COMESA Simplified Trade Regime, and all these documents demand processing fee and duty stamp fees which most traders reported that they could not afford. Traders perceived that they were being double taxed on both sides of the borders and that some unscrupulous officials were corrupt and demanded bribes, agreeing to the study conducted by Makombe [24].

\section{Conclusions and Recommendations}

In summary, the small pelagic fish species are the most traded in both Malawi and Zambia, and there is a great market potential for small fishes trade, as they are affordable to the low income household, hence demanding the much need attention to develop a sustainable management regime for these fish species 
in order to maximize benefits out of it for both the traders and final consumers. Also, this calls for the need to regularize trade in small pelagic fish species involving artisanal traders, since it plays a great role in their livelihood and also food and nutrition security. Fish traders use informal trade routes due to unscrupulous policies guiding the cross-border trade, and also the traders were put off by the cross-border trade regulations.

Therefore, on the basis of the study, it is important for countries in the SADC region to regularize and formalize cross-border trade in small pelagic fish species, since this species plays a great role in the livelihoods and food and nutrition security of many people in the region, especially the rural and urban poor. It is also important for governments to support processors and traders to improve the quality of fish being traded, enhance access of traders to cross-border fish market information, decentralize issuing of the import/export certificates and other cross-border support documents, and enhance informal trade monitoring systems to adequately quantify the volumes and trade flows.

\section{Acknowledgments}

Special thanks to WorldFish Center, the African Union Inter-African Bureau for Animal Resources (AU-IBAR) and NEPAD Planning and Coordinating Agency (NPCA) for funding the research under the Fish Trade Project "Improving Food Security and Reducing Poverty through Intra-regional Fish Trade in Sub-Saharan Africa", following the Malabo Declaration. The funding was made possible through the assistance from the European Union.

\section{References}

[1] Food and Agriculture Organization of the United Nations (FAO). 2016. State of World Fisheries and Aquaculture 2016. Rome: Fisheries and Aquaculture Department, FAO.

[2] United Nations. 2013. Economic Development in Africa Report 2013: Intra-African Trade: Unlocking Private Sector Dynamism. Geneva: United Nations.
[3] Food and Agriculture Organization of the United Nations (FAO). 2014. State of World Fisheries and Aquaculture 2014. Rome: Fisheries and Aquaculture Department, FAO.

[4] United Nations Conference on Trade and Development. 2013. World Investment Report 2013: Global Value Chains: Investment and Trade for Development. New York: United Nations.

[5] World Trade Organization. 2014. World Trade Report 2014.

[6] Abbott, J. G., Hay, C. J., Næsje, T. F., Tweddle, D., and Van der Waal, B. C. W. 2015. "Rain and Copper: The Evolution of a Fish Marketing Channel in a Rapidly Changing Region of Southern Africa." Journal of Southern African Studies 41 (1): 29-45. http://dx.doi. org/10.1080/03057070.2015.991619.

[7] African Union Commission. 2014. Malabo Declaration on Accelerated Agricultural Growth and Transformation for Shared Prosperity and Improved Livelihoods. Doc. Assembly/AU/2(XXIII).

[8] Food and Agriculture Organization of the United Nations (FAO). 2012. State of World Fisheries and Aquaculture 2012. Rome: Fisheries and Aquaculture Department, FAO.

[9] Shortte, F. 2013. Promoting Sustainable Fish Trade between CARICOM States and Their Trading Partners the EU and US: The Case of St Vincent and the Grenadines. Research Paper, United Nations-Nippon Foundation of Japan Fellowship Programme.

[10] Kachere, W. 2011. The Southern Africa Development Community: The Case of Zimbabwe. Department of Development Studies, Faculty of Management and Commerce, University of Fort Hare, South Africa.

[11] Dec, J. A. S. O. N. 2008. Informal Cross Border Food Trade in Southern Africa. Washington, D.C.: Famine Early Warning Systems Network.

[12] Cornelius, W. A. 1982. "Interviewing Undocumented Immigrants: Methodological Reflections Based on Fieldwork in Mexico and the U.S." International Migration Review 16 (2): 378-411.

[13] Ama, N. O., Mangadi, K. T., Okurut, F. N., and Ama, H. A. 2013. "Profitability of the Informal Cross-Border Trade: A Case Study of Four Selected Borders of Botswana." African Journal of Business Management 7 (40): 4221-32.

[14] Ellis, S., and MacGaffey, J. 1996. "Research on Sub-Saharan Africa's Unrecorded International Trade: Some Methodological and Conceptual Problems." African Studies Review 39 (2): 19-41.

[15] Ackello-Ogutu, C. 1996. Methodologies for Estimating Informal Cross-Border Trade in Eastern and Southern Africa: Kenya/Uganda Border, Tanzania and Its 
Neighbors, Malawi and Its Neighbors, Mozambique and Its Neighbors. Technical Paper No. 29. USAID/Bureau for Africa. Office of Sustainable Development.

[16] Economic Commission for Africa. 2010. Assessing Regional Integration in Africa IV: Enhancing Intra-African Trade. Economic Commission for Africa. Accessed January 13, 2016. http://mcli.co.za/mcli-web/ downloads/ARIA4/toc.pdf.

[17] United Nations Development Fund for Women. 2009. "Unleashing the Potential of Women Informal Cross Border Traders to Transform Intra-African Trade." United Nations Entity for Gender Equality and the Empowerment of Women (UN Women). Accessed January 20, 2016. http://www.unwomen.org/en/digitallibrary/publications/2010/3/unleashing-the-potential-of-w omen-informal-cross-border-traders-to-transform-intra-af rican-trade\#sthash.TekbluHJ.dpuf.

[18] Africa, J. K., and Ajumbo, G. 2012. "Informal Cross Border Trade in Africa: Implications and Policy Recommendations." African Development Bank (AFDB), Africa Economic Brief 3 (10).

[19] Government of Malawi. 2014. Annual Economic Report 2014. Ministry of Development Planning and Cooperation
Budget Document No. 2. Malawi Government, Malawi.

[20] FEWS NET. 2015. Informal Cross Border Food Trade in Southern Africa. Washington D.C.: FEWS NET. http://www.fews.net/sites/default/files/documents/reports/ Food $\% 20$ Trade $\% 20$ bulletin $\% 20$ April $\% 202014 \% 20$ to $\% 2$ 0March\%202015.pdf.

[21] Department of Fisheries. 2017. 2016 Department of Fisheries Annual Report. Department of Fisheries, Ministry of Fisheries and Livestock, Lusaka, Zambia.

[22] Ntara, M. M., Hebinck, P. G. M., and Van Dijk, J. W. M. 2014. "In the Shadow of Global Markets: Fish Markets in Mwanza, Tanzania." In Rural Development and the Construction of New Markets. London: Routledge, 168-90.

[23] Harms, W. 2011. "Women Less Interested than Men in Jobs Where Individual Competition Determines Wages.' Chicago News. Accessed January 14, 2011. https://news.uchicago.edu/article/2011/01/14/women-less -interested-men-jobs-where-individual-competition-deter mines-wages.

[24] Makombe, P. F. 2011. "Informal Cross-Border Trade and SADC: The Search for Greater Recognition." Open Society Initiative for Southern Africa 44-9.

\section{Appendixes}

Appendix 1 Magnitude of informal fish trade in Malawi.

\begin{tabular}{|c|c|c|c|c|c|c|}
\hline Trade partner & Border post recorded & $\begin{array}{l}\text { Imports } \\
\text { (tonnes) }\end{array}$ & $\begin{array}{l}\text { Exports } \\
\text { (tonnes) }\end{array}$ & $\begin{array}{l}\text { Total } \\
\text { (tonnes) }\end{array}$ & $\begin{array}{l}\text { Value } \\
\text { (Malawi Kwacha) }\end{array}$ & $\begin{array}{l}\text { Value } \\
\text { (US\$) }\end{array}$ \\
\hline Mozambique & $\begin{array}{l}\text { Muloza } \\
\text { Marka } \\
\text { Mwanza } \\
\text { Dedza } \\
\text { Chiponde }\end{array}$ & $14,481.84$ & $16,584.48$ & $31,066.32$ & $37,703,524,068.68$ & $52,366,005.64$ \\
\hline Zambia & Mchinji & - & $11,399.20$ & $11,399.20$ & $15,542,982,056.00$ & $21,587,475.07$ \\
\hline Tanzania & Songwe & - & $2,820.00$ & $2,820.00$ & $5,895,568,695.65$ & $8,188,289.85$ \\
\hline Total & & $14,481.84$ & $30,803.68$ & $45,285.52$ & $59,142,074,820.33$ & $82,141,770.56$ \\
\hline
\end{tabular}

-: Not applicable.

Appendix 2 Magnitude of informal fish trade in Zambia.

\begin{tabular}{lllllll}
\hline Trade partner & Border post recorded & $\begin{array}{l}\text { Imports } \\
\text { (tonnes) }\end{array}$ & $\begin{array}{l}\text { Exports } \\
\text { (tonnes) }\end{array}$ & $\begin{array}{l}\text { Total } \\
\text { (tonnes) }\end{array}$ & $\begin{array}{l}\text { Value } \\
\text { (Zambian Kwacha) }\end{array}$ & $\begin{array}{l}\text { Value } \\
\text { (US\$) }\end{array}$ \\
\hline Mozambique & Luangwa & $3,228.59$ & - & $3,228.59$ & $968,577.27$ & $103,040.14$ \\
Tanzania & Nakonde & $1,642.50$ & - & $1,642.50$ & $492,750.00$ & $52,420.21$ \\
Namibia & Katimamulilo & 273.75 & - & 273.75 & $82,125.00$ & $8,736.70$ \\
DRC & Kasumba Lesa & - & $97,119.06$ & $97,119.06$ & $29,135,718$ & $3,099,544.47$ \\
\hline Total & & $5,144.84$ & $97,119.06$ & $102,263.90$ & $30,679,170.27$ & $3,263,741.52$ \\
\hline
\end{tabular}

-: Not applicable. 